\title{
LEGAL PLURALISM, INSTITUTIONALISM AND JUDICIAL RECOGNITION OF HONG KONG-CHINA CROSS-BORDER INSOLVENCY JUDGMENTS
}

\author{
Emily Lee*
}

Legal pluralism and institutionalism are important theoretical underpinnings for the discourses of judicial recognition under dual legal systems that coexist within one sovereign nation such as the case of China and Hong Kong. Institutionalism provides that only formal institutions (eg, constitutions, laws and treaties), unlike informal ones (eg, private contracts, traditions and customs), can facilitate judicial recognition and enforcements for insolvency creditor rights protection. Legal pluralism, however, provides for an alternative to circumventing political sovereignty issues typically associated with the making of treaties for mutual judicial recognition purposes. Under the Chinese politico-legal system, Hong Kong is a Special Administrative Region which is akin to a province; as such, Hong Kong is not qualified to sign a bilateral treaty with China. This article expounds and analyses why instituting and implementing a special arrangement (an alternative to a treaty) can help optimise the mutual enforcement of Hong Kong-China cross-border insolvency judgments and orders.

\section{Introduction}

Legal pluralism is a notion that is both expansive and non-fixated; it can be legal theory, for it is discourse about the law; it is also jurisprudence, as it attempts to capture what the law is and what form or forms a substantive law should take. ${ }^{1}$ In practice, legal pluralism denotes

\footnotetext{
* Dr Emily Lee, Assistant Professor, Faculty of Law, University of Hong Kong; Affiliated International Scholar, National Centre for Business Law in Vancouver, Canada. The author gratefully acknowledges the hospitality and the support of the Centre for Chinese Research at the Institute of Asian Research, University of British Columbia, where this work was initiated. The author would especially like to thank Professor Dr Pitman Potter for sharing his inspirational thoughts on legal pluralism which provides the theoretical basis for examining the China-Hong Kong (SAR) politico-legal system.

${ }^{1}$ Emmanuel Melissaris, "The More the Merrier? A New Take on Legal Pluralism" (2004) 13(1) Social and Legal Studies 57, 58.
} 
and emphasises the fact that alternatives coexist because they reflect the different considerations (eg, political, economic or social) and functions that a particular law is designed to attain. This article is about the judicial recognition of cross-border corporate insolvencies (CBIs) between Hong Kong and China (HK-China CBI) and how it can be sought and then granted through a number of ways: a special arrangement (the details of which will be expounded below); a memorandum of understanding (MoU) or private contracts (collectively referred to as "the alternatives"), depending on who is the applicant (ie, a judicial court or private litigants) lodging a petition for judicial assistance.

HK-China CBI matters belong to neither domestic law nor international law. In discerning the particular type of conflict of laws issues in $\mathrm{HK}-\mathrm{China} \mathrm{CBI}$ matters from those typically associated with private international law, the "regional conflict of law" theory was invented (further details below) for attaining this goal. In order to enforce insolvency judgments that have cross-border implications, a mutual judicial recognition mechanism is required. In the context of this article, $\mathrm{CBI}$ judgments refer to those made by the courts in Hong Kong or China which would be enforced in the counterparty's jurisdiction. For example, CBI judgments or orders made by the Hong Kong courts need to be recognised by the Chinese courts prior to being enforced in the counterparty jurisdiction (ie, China) and vice versa. Judicial assistance or recognition is usually sought in two circumstances: first, the courts in Hong Kong can seek cooperation from their counterparty courts in China in order to validate a claim raised by a creditor in Hong Kong against an insolvent debtor company in China; second, a private party in Hong Kong may want to obtain judicial recognition from a Chinese court in order to enforce a favourable judgment made by the Hong Kong court; this is especially the case if the main assets of the debtor company are located in China.

Different circumstances call for different resolutions; the result is often that a particular alternative will be deployed in favour of others because it is designed for a specific 
desired aim of the concerned parties. For example, in seeking judicial assistance or recognition, acquiring a readily obtainable court order in a friendlier provincial court in China is often preferable to relying on a MoU. An enforcement action cannot always be efficiently carried out by deploying a MoU because it may fail to bring forth a timely resolution prior to the debtor company's assets being dissipated or grabbed by other creditors who are located in the same jurisdiction (eg, in China) as the debtor company and thus have easier access to the debtor company's assets and businesses.

Distinct advantages can be built into and associated with different alternatives, making their coexistence not only possible but also preferable - an important advantage and fundamental strength to legal pluralism. The opposite is also true: all alternatives available for deployment have limitations or disadvantages. Three exemplary alternatives can be qualified for demonstrating this point. First, a treaty is a formal judicial recognition mechanism which can warrant judicial assistance and recognition entitlements; however, entering into a bilateral treaty between Hong Kong and China for the very purpose of judicial assistance and recognition is impossible, given the political relationship between China and Hong Kong, a Special Administrative Region (SAR) within China which is a subordinated region of its sovereign (China) and not an independent state which can otherwise be capacitated to sign a treaty. Under the Chinese politico-legal system, the level of a SAR government is akin to that of a provincial government. Hong Kong's political status will thus prevent it from signing a bilateral treaty with its sovereign (China) because a treaty must be signed between state authorities and Hong Kong does not qualify as one. Second, a MoU, although it is likely to provide judicial assistance and recognition for judgments or court orders concerning HK-China CBI matters, many MoUs are usually signed between horizontal parties; for example, between certain provinces or between certain courts for achieving a predetermined and prescribed purpose of mutual judicial cooperation, assistance 
and recognition. Third, under private contracts, private parties can, prior to any incurrence of legal disputes, sign a written agreement to designate a people's court in China or a court in Hong Kong as the forum to have sole jurisdiction for resolving disputes (ie, Choice of Court Agreement). ${ }^{2}$ Private contracts would likely have the greatest limitations to constitute as a viable alternative for judicial recognition purposes; a Choice of Court Agreement is not suitable for CBI matters because in many of these cases, the court jurisdiction is established on a non-consensual basis.

Pluralism, in shape and form, is guided by "adaptive efficiency", which is a theory pertaining to the development of purposive alternatives that are bolstered by incentives. ${ }^{3}$ Adaptive efficient institutions (including treaties, MoUs and private contracts) do exist and coexist; one alternative does not preclude or diminish the other because each alternative embodies a preferential value pursued by concerned parties in exploring problem-solving mechanisms for judicial assistance and recognition of HK-China CBI matters. ${ }^{4}$ In other words, treaties, MoUs and private contracts serve different purposes and thus have different mandates that empower their respective existence. Positioned at different hierarchical levels, from the lowest (private contracts) to the highest (treaties), the normative order implicates the dynamics of these institutions customarily designed for judicial assistance and recognition. Since there is a lack of a formal judicial assistance and recognition mechanism for $\mathrm{HK}-\mathrm{China}$ CBI cases, filling the void would serve and preserve a socioeconomic value due to the massive cross-border trade between Hong Kong and China. China is Hong Kong's largest trading partner and Hong Kong is China's fourth-largest trading partner and third-largest export market, with cross-border trade volume worth US\$103.49 billion from January to

\footnotetext{
${ }^{2}$ Supreme People's Court, "Key Features of the Arrangement on Reciprocal Recognition and Enforcement of Judgments in Civil and Commercial Matters by the Courts of the Mainland and of the Hong Kong Special Administrative Region Pursuant to Choice of Court Agreements between Parties Concerned", Art 2(b).

${ }^{3}$ Douglass C North, Institutions, Institutional Change and Economic Performance (Cambridge: Cambridge University Press, 1990) 81.

${ }^{4}$ Ibid., pp 81-82.
} 
April 2014, according to statistics published by China's Ministry of Commerce on 10 June 2014..$^{5}$ Also, in April 2014, the Securities and Futures Commission (the SFC, Hong Kong's securities industry regulator) indicated that the aggregate quotas for the cross-border trade of Hong Kong-listed stocks was 250 billion yuan (equivalent to about US\$40 billion) and of Shanghai-listed stocks was 300 billion yuan (equivalent to about US $\$ 48$ billion). ${ }^{6}$ In light of the SFC's findings, it is fair to suggest that a normative order at the socioeconomic level needs to be put in place; institutions can be deployed to fulfil a host of legal claims concerning enforcement rights. Institutions, formal and informal, contribute to the conceptualising and functioning of legal pluralism. Any institutional alternative - whether it be a treaty, MoU or private contract - should meet the legal pluralism's objective of practicality; such as, for the purpose of this article, facilitating creditors' rights protection which is the quintessence of The World Bank's Principles for Effective Insolvency and Creditor Rights Systems. ${ }^{7}$ It is predicted that the proposed judicial recognition mechanism for HK-China CBI cases, once in place, will have a long-term impact on Hong Kong and China.

In the Hong Kong-China politico-legal system, legal pluralism stems from and crosses over with path dependency, a theory that describes why "the apple does not fall far from the tree". Insights from the path dependency theory can be drawn to explain why Hong Kong adopted and continues to follow the British common law system even after it reverted to Chinese sovereignty and became the Hong Kong SAR (HKSAR) on 1 July 1997. The history of British colonial rule over Hong Kong from 1841 to 1997 (excluding the Japanese

\footnotetext{
${ }^{5}$ Ministry of Commerce of the People's Republic of China, "Mainland-Hong Kong Economic and Trade Cooperation in January-April 2014" (10 June 2014), available at http://english.mofcom.gov.cn/article/statistic/lanmubb/hkmacaotaiwan/201406/20140600642371.shtml (visited 6 July 2014).

${ }^{6}$ Shidong Zhang and Kana Nishizawa, "Hong Kong, China Stocks Jump on Cross-Border Trade Deal" Bloomberg News (10 April 2014), available at http://www.bloomberg.com/news/2014-04-10/china-s-stocks-arelittle-changed-before-release-of-trade-data.html (visited 6 July 2014).

${ }^{7}$ World Bank's Principles for Effective Insolvency and Creditor Rights Systems, available at http://www.eisil.org/index.php?sid=4ails\&id=1120\&t=link_details\&cat=642 and http://www.worldbank.org/ifa/ipg_eng.pdf (visited 15 July 2014).
} 
occupation from 1941 to 1945) provides an opportunity to reflect on the common law tradition which guides and informs the legal system in Hong Kong - even in the modern day. Given that context, legal pluralism, or more generally sociocultural pluralism, "provides a path-dependent pattern of institutional evolution". ${ }^{8}$ History matters because "we cannot understand today's choices ... without tracing the incremental evolution of institutions"9 such as the legal system in general and the insolvency regime in particular in Hong Kong.

After Hong Kong became the HKSAR, the first formal judicial recognition mechanism for cross-border instances lay with the Arrangement on Reciprocal Recognition and Enforcement of Judgments in Civil and Commercial Matters by the Courts of the Mainland and of the Hong Kong Special Administrative Region Pursuant to Choice of Court Agreements between Parties Concerned (the 2006 Arrangement), which was signed in Hong Kong on 14 July 2006 by the Secretary for Justice of the HKSAR (Mr Yan-lung Wong) and the Vice President of the Supreme People's Court of China (Mr Songyou Huang J). ${ }^{10}$ The 2006 Arrangement was adopted at the 1,390th Meeting of the Judicial Committee of the Supreme People's Court on 12 June 2006 and it took effect on 1 August 2008. However, as its name suggests, the 2006 Arrangement applies only to civil and commercial matters and is not extended to cover HK-China CBI cases. It is important to note that the 2006 Arrangement cannot be adapted to create a new judicial recognition mechanism for $\mathrm{HK}-$ China CBI cases unless it is substantially revised. The 2006 Arrangement applies only to civil and commercial cases under the consensual jurisdiction by the parties. In other words, the 2006 Arrangement builds around the parties' choice of jurisdiction (to be in either Hong Kong or China); this is not suitable for CBI matters because in many CBI cases, the court

\footnotetext{
${ }^{8}$ North (n 3 above), p 98.

${ }^{9}$ Ibid., p 100.

${ }^{10}$ Xianchu Zhang and Philip Smart, "Development of Regional Conflict of Laws: On the Arrangement of Mutual Recognition and Enforcement of Judgments in Civil and Commercial Matters between Mainland China and Hong Kong SAR” (2006) 36 Hong Kong Law Journal 553.
} 
jurisdiction is established on a non-consensual basis. Also, the 2006 Arrangement envisaged a commercial contractual relationship between the litigating parties and applies only to limited types of judgments - specifically, to "monetary judgments relating to commercial contracts". Consequently, the 2006 Arrangement "limited the category of enforceable judgments to money award concerning commercial contracts; that are final and conclusive; rendered by the Hong Kong Courts above the district level or the People's Courts above intermediate level; and on a basis of parties' consented jurisdiction" (emphasis added) ${ }^{11}$ Given that the 2006 Arrangement concerns only "monetary judgments", it excludes insolvency orders or judgments that are non-monetary but aim to facilitate the procedural requirement such as the appointment of liquidators. This means that the 2006 Arrangement is incompatible for adaptation for HK-China CBI cases. The legal lacuna and the unsettled CBI issue is of concern to interested parties ${ }^{12}$ located in both jurisdictions; it also leaves unanswered the question of whether a new mutual recognition mechanism (apart from the 2006 Arrangement) can be constructed that focuses on HK-China CBI cases; and if or when it is in place, it shall greatly increase the chance of enforceability within China of a judicial decision made in Hong Kong. In another article, ${ }^{13}$ the author examined methods and options available to fill the legal lacuna and resolve the unsettled CBI issue: specifically (1) whether it is legally possible to extend the 2006 Arrangement to cover HK-China CBI matters (and if so, what the practical concerns might be and what changes may be required for making this option practically implementable); (2) whether a bilateral agreement or treaty that focuses on mutual judicial recognition of HK-China CBI judgments will likely be signed; or (3) whether Hong Kong and Chinese courts would sign MoU for CBI judicial recognition.

\footnotetext{
${ }^{11}$ Ibid., p 562.

12 The interested parties include the debtor company and its shareholders and creditors, stakeholders such as the investing public, government policymakers on cross-border trade and insolvency practitioners in Hong Kong and China.

${ }^{13}$ Emily Lee, "Problems of Judicial Recognition and Enforcement in Cross-Border Insolvency Matters between Hong Kong and Mainland China" (2015) 63(2) American Journal of Comparative Law (forthcoming).
} 
By way of extended discussion, this article intends to address the scholarly gap by analysing the institutional structure underlying the regional conflict of laws issue between Hong Kong and China and addressing the pluralistic alternatives in developing a formal judicial recognition mechanism for HK-China CBI matters. Given that institutions can be formal and informal, the mechanism's particular institutional form could be either (1) a special arrangement that focuses on HK-China CBI matters; or (2) a MoU between Hong Kong and Chinese courts; or (3) a private party Choice of Court Agreement. Under the rubric of legal pluralism, all three alternatives can coexist since each of them embodies the value of certain legal utility function represented by them - whether it is to uphold a special arrangement/MoU obligation or honour contractual freedoms. Although HK-China CBI disputes frequently occur and a customised solution is long overdue, there is no sign of developing any formal judicial assistance and recognition mechanism in light of this issue in the near future. In practice, insolvency practitioners appointed in Hong Kong must be innovative and strategically plan for any subsequent insolvency proceedings to take place in China: for example, taking action such as changing legal representatives and management personnel of Chinese subsidiary companies is one important way to achieve this aim, although this would mean that administrative measures would be employed to achieve a result that a clearly stated insolvency procedure should bring forth as a matter of course and with legal certainty for all concerned parties. ${ }^{14}$ Changing legal representatives has a certain innovative aspect to it, if it is viewed as a way to sidestepping the problem of having no formal judicial assistance and recognition mechanism for $\mathrm{HK}-\mathrm{China} \mathrm{CBI}$ cases.

Understandably, a change of legal representatives is not intrinsic to corporate insolvencies as it can also happen where there is a shareholder dispute. And even if a change of legal representatives helps in creditors' rights enforcement, it would be left at the vagary of

\footnotetext{
${ }^{14}$ Securities and Futures Commission v China Metal Recycling (Holdings) Ltd HCCW 210/2013; China Metal Recycling (Holdings) Ltd v Chun Chi Wai HCA 1412/2013.
} 
China's Administration for Industry and Commerce which may or may not permit it. Judicial recognition is a rather practical issue; the Chinese courts usually would not have any problem recognising the liquidators or provisional liquidators who are appointed by Hong Kong courts provided that the company in liquidation is incorporated in Hong Kong. However, the Administration for Industry and Commerce may respect or otherwise delay the order given by the Chinese court to allow the change of legal representatives. ${ }^{15}$

This article first lays out the analytical framework for legal pluralism and then demonstrates how legal pluralism and institutional rules can apply to the regional conflict of laws issue borne from the HK-China CBI disputes. Part one of this article consists of the regional conflict of laws issue stemming from the application of different insolvency laws in Hong Kong and China; Sally Engle Merry’s legal pluralism theory on legal system implantation of the Hong Kong legal system in the other (ie, in China) to create institutional value for legal harmonisation; and the author's proposed formal judicial recognition mechanism in the form of a special arrangement. Following on from this, Part two of this article demonstrates how formal and informal institutions interplay with the operation of insolvency laws in Hong Kong and China with regard to HK-China CBI matters. In the time and space available, Part three of this article goes on to address some of the many issues that combine both institutionalism and legal pluralism theories for testing the institutional value of legal pluralistic alternatives. The author concludes this article by suggesting a more radical solution for streamlining the mutual enforcement procedure and reducing unwanted duplicative insolvency proceedings and the accompanying legal costs through devising a special arrangement which is modelled after the 2006 Arrangement but focuses instead on HK-China CBI matters.

\footnotetext{
${ }^{15}$ For details, see Lee (n 13 above).
} 


\section{Legal Pluralism}

\section{Background: Regional Conflict of Laws}

Theoretical underpinnings regarding regional conflict of laws (also referred to by some commentators such as Goubin Zhu as inter-regional conflict of laws) are in place for dealing with conflict of laws cases involving the courts in Hong Kong and the courts in China. In fact, Hong Kong and China have different insolvency laws which are respectively guided by different legal traditions. In Hong Kong, although it does not have a uniform corporate insolvency law, statutory provisions relating to corporate insolvency are embedded in the Companies Ordinance (Cap 32) ${ }^{16}$ and its subsidiary legislation such as the Companies (Winding-up) Rules; in China, the Enterprise Bankruptcy Law (EBL) ${ }^{17}$ is China's uniform corporate insolvency law. Furthermore, Hong Kong's insolvency system is modelled after the UK Insolvency Act of 1986, while China's insolvency regime was developed indigenously until it was superseded by the 2006 EBL which is modelled after the US Bankruptcy Code. Due to different insolvency laws in China and Hong Kong, CBI cases that straddle both these jurisdictions are known as "HK-China CBI cases" and often involve the complex regional conflict of laws issue. In Hong Kong, there are no cross-border provisions in its corporate insolvency law, specifying the manner which judicial recognition or assistance in CBI matters is to be given. A foreign judgment may be enforced in Hong Kong either by statutes or at common law. The signing of the 2006 Arrangement resulted in the enactment of the Mainland Judgments (Reciprocal Enforcement) Ordinance (Cap 597), which is now part of Hong Kong law. However, the 2006 Arrangement does not cover HK-China CBI matters. In

\footnotetext{
16 The Laws of Hong Kong, Companies Ordinance, available at http://www.legislation.gov.hk/blis_pdf.nsf/4f0db701c6c25d4a4825755c00352e35/BFBC0BDE18CA066548257 5EE0030D882/\$FILE/CAP_32_e_b5.pdf (visited 15 July 2014).

17 The EBL was promulgated on 27 August 2006 and came into effect on 1 June 2007. For details about the regulatory development of and reform towards the EBL, which is emblematic of the Chinese legislators' collective efforts in building a comprehensive bankruptcy system in China, see "China: Global Norms with "Chinese Characteristics"” in Terence C Halliday and Bruce G Carruthers, Bankrupt-Global Law Making and Systemic Financial Crisis (Stanford, CA: Stanford University Press, 2009) 247-292.
} 
China, although Article 5 of the EBL made provisions for recognition and enforcement of foreign corporate insolvency judgments, it does not provide any mechanism to facilitate CBI matters, neither between two independent states nor between the HKSAR and China. It is important to note that Article 5 of the EBL refers expressly to "the courts of foreign countries", which practically excludes the Hong Kong courts from relying on this specific provision to seek judicial recognition or assistance from the Chinese courts.

Judicial recognition of $\mathrm{HK}-\mathrm{China} \mathrm{CBI}$ matters strongly implicates the regional conflict of laws issue due to the fact that before Hong Kong was returned to Chinese sovereignty, Hong Kong was regarded as a foreign jurisdiction by China; and ironically, even after the return of Hong Kong to China in 1997, Hong Kong is still regarded as a foreign jurisdiction by China (further details below). As such, CBI judgments or orders made by the Hong Kong courts need to be recognised by the Chinese courts prior to being enforced in the counterparty jurisdiction (ie, China) and vice versa. The HK-China relationship is now governed by Hong Kong's Basic Law, the SAR's de facto constitution under the "One Country, Two Systems" principle. Although Article 153 of the Basic Law provides that international agreements can be applied to Hong Kong, cross-border matters between Hong Kong and China are not part of the "external affairs" governed by Chapter VII of the Basic Law, to which Article 153 belongs. That is because the "external affairs" referred to hereinabove will inevitably involve a foreign state which excludes Hong Kong.

Furthermore, the United Nations Commission on International Trade Law (UNCITRAL) Model Law on Cross-Border Insolvency (the Model Law) does not apply to HK-China CBI cases, unless a third jurisdiction (other than Hong Kong and China) is involved. It should be emphasised that the border between Hong Kong and China is not a border as is usually understood in the context of the Model Law. In the context of the Model Law, the term "foreign" is used to describe a collective judicial or administrative proceeding 
in a "foreign State", which intrinsically excludes Hong Kong due to its status as a SAR within its sovereign, China. ${ }^{18}$ As such, it is important to note that, although internationally accepted soft law standards such as the Model Law provides institutional guidance to CBI matters, it is not entirely compatible with HK-China CBI cases, unless and until those matters involve a third jurisdiction and that third jurisdiction is typically a tax haven jurisdiction which is exemplified by those in Bermuda, the British Virgin Islands (BVI) or the Cayman Islands. Moreover, since neither Hong Kong nor China has adopted the Model Law, there is a divergence of Hong Kong's insolvency law from China's EBL which cannot be easily amended by applying universal insolvency soft law standards such as those set out in the Model Law. In reality, among the few countries that have adopted the Model Law into their domestic insolvency laws, many have amended it (the Model Law) contrary to the intention of the drafters. Consequently, it is reasonable to expect that the international protocols set by the Model Law can be breached, if and when the national insolvency law does not conform with the Model Law or if the court presiding over the insolvency case chooses not to adopt it.

\section{Legal Pluralism}

Legal pluralism concerns the discourses about the law in conjunction with the creation of purposive alternatives (ie, legal institutions) for attaining a specific normative purpose. The normative purpose in question is the author's investigation of and exhortation to creating a formal mechanism that makes possible the granting of judicial assistance and recognition for HK-China CBI cases by and between Hong Kong and Chinese courts. A range of legal institutions can be developed (eg, MoU or private parties' Choice of Court Agreement) or explored (such as a special arrangement proposed by the author). The overarching goal is to more consistently implement insolvency laws in both Hong Kong and China. A hermeneutics

18 UNCITRAL Model Law on Cross-Border Insolvency (1997), Art 2. 
of legal pluralism examines how many purposive alternatives can be tolerated in one legal system. $^{19}$

A historical trajectory paves the way for and ultimately results in the upholding of dual legal systems within one sovereign nation, the People's Republic of China (China). The signing of the Joint Declaration of the Government of the People's Republic of China and the Government of the United Kingdom of Great Britain and Northern Ireland on the Question of Hong Kong (the Sino-British Joint Declaration) ${ }^{20}$ on 19 December 1984 declared that Hong Kong would be returned to China as the HKSAR on 1 July 1997. The Sino-British Joint Declaration was an agreement between China and the UK, guaranteeing Hong Kong's freedoms and pluralism under the rule of law for 50 years from 1 July 1997 onwards. Within six years of the handover, on 29 June 2003, China and the HKSAR sought to foster and facilitate bilateral trade between the two economic entities by signing the Closer Economic Partnership Arrangement which laid out the basis for economic integration between China and the HKSAR under the political arrangement of the "One country, Two systems" principle so that the HKSAR's capitalist and China's socialist economies can coexist under the same sovereign nation but operate within separate legal and business frameworks. Yet China and the HKSAR still remained, and continue to remain, two separate judicial jurisdictions. There is separation because, before Hong Kong was returned to Chinese sovereignty, Hong Kong was regarded as a foreign jurisdiction by China and, as such, judicial recognition between them was sought through international conventions, namely the New York Convention ${ }^{21}$ and

\footnotetext{
${ }^{19}$ Teemu Ruskola, "Conceptulising Corporations and Kinship: Comparative Law and Development Theory in a Chinese Perspective" (2000) 52(6) Stanford Law Review 1599.

20 The Sino-British Joint Declaration, available at http://www.legislation.gov.hk/blis_ind.nsf/CurAllEngDoc/034B10AF5D3058DB482575EE000EDB9F?OpenD ocument (visited 8 July 2014).

${ }^{21}$ The full title of New York Convention is "the Convention on the Recognition and Enforcement of Foreign Arbitral Awards of 1958".
} 
the Hague Convention. ${ }^{22}$ The UK extended the Hague Convention to Hong Kong in 1970; subsequently, the UK also extended the New York Convention to Hong Kong in 1975. Ironically, even after the return of Hong Kong to China in 1997, Hong Kong is still regarded as a foreign jurisdiction by China; this may be evidenced by a judicial interpretation issued in 2002 by the Supreme People's Court in China titled "Provisions Concerning the Jurisdiction Problems of Foreign-Related Civil and Commercial Cases" (emphasis added), whose Article 5 prescribes that "the jurisdiction of civil and commercial cases involving HKSAR, Macao SAR and Taiwan litigants shall be solved by referring to the Provision". ${ }^{23}$ As a result, judicial assistance and recognition of court judgments and orders remain a problem between the HKSAR and China.

Hong Kong's English common law-influenced legal system runs parallel to, while nestled within, the civil law-oriented Chinese legal system; the idiosyncrasy of the dual legal system operating simultaneously within one sovereign nation (ie, China) echoes Sally Engle Merry's legal pluralism theory which coincides with British colonialism:

"British colonialism in particular emphasised the creation of a dual legal system ...

Legal pluralism is not a theory of law or an explanation of how it functions, but a description of what law is like. It alerts observers to the fact that law takes many forms and can exist in parallel regimes. It provides a framework for thinking about law, about where to find it and how it works. As such, legal pluralism provides an invaluable guide to thinking about law in its multiple instantiations and intersections and to paying attention to alternative understandings and practices of law...".24

\footnotetext{
${ }^{22}$ The full title of Hague Convention is "the Convention on the Service Abroad of Judicial and Extrajudicial Documents in Civil and Commercial Matters of 1965".

${ }^{23}$ Xinyi Gong, "When Hong Kong Becomes SAR, Is the Mainland Ready? Problems of Judgments Recognition in Cross-Border Insolvency Matters" (2011) 20 International Insolvency Review 57, 58.

24 Sally Engle Merry, "Legal Pluralism in Practice" (2013) 59 McGill Law Journal 1.
} 
Merry's treatise on legal pluralism is a systematic exposition of how to implant one legal system (in Hong Kong) in another (in China) to create a valued-added framework that creates institutional value for legal harmonisation of the two systems. The legal framework governing judicial recognition by the Hong Kong and Chinese courts has historical underpinning. Tamanaha says legal pluralism is a common historical condition and new forms of legal pluralism were created through colonisation that could combine the insights from comparative law and international law. ${ }^{25}$ To this end, the UK Insolvency Act of 1986, the US Bankruptcy Code and the Model Law will likely continue to influence the shaping of regional conflict of laws development inside Hong Kong and China. Since the courts in both Hong Kong and China play an important role in cross-border insolvency cases,${ }^{26}$ insights from global studies on communications between courts and intermediaries (eg, liquidators), exemplified in UNCITRAL Model Law on Cross-Border Insolvency: The Judicial Perspective ${ }^{27}$ can help stakeholders in HK-China CBI matters better gauge whether the views of the respective courts in Hong Kong and China align with international principles on judicial recognition.

Legal pluralism has both advantages and disadvantages. Although the pluralism theory allows for various alternative systems to coexist for providing different legal functions that suit different parties' resolution plan, it may come at a price. Legal pluralism could inadvertently generate problems of uncertainty and encourage opportunistic behaviour such as forum shopping by creditors who are better-informed or financially resourceful, at the expense of other creditors. While legal pluralism denotes flexibility and diversity in legal

\footnotetext{
${ }^{25}$ Brian Z Tamanaha, "Understanding Legal Pluralism: Past to Present, Local to Global" (2008) 30 Sydney Law Review 375, 376.

${ }^{26}$ Bob Wessels, "The Role of Courts in Solving Cross-Border Insolvency Cases" (2011) 24 Insolvency Intelligence 1-9.

${ }^{27}$ UNCITRAL Model Law on Cross-Border Insolvency: The Judicial Perspective (2013).
} 
forms and functions, its inherent problems have been portrayed by Tamanaha in his critical discourse analysis below:

"What makes this pluralism noteworthy is not merely the fact there are multiple uncoordinated, co-existing or overlapping bodies of law, but that there is diversity among them. They may have competing claims of authority; ... they may have different styles and orientations. This particular conflict can generate uncertainty or jeopardy for individuals and groups in society who cannot be sure in advance which legal regime will be applied to their situation. This state of conflict also creates opportunities for individuals and groups within society, who can opportunistically select from among coexisting legal authorities to advance their claims". (Emphasis added $)^{28}$

If we opt to apply Tamanaha's legal pluralism analysis to HK-China CBI matters, since the regional conflict of laws originates from different insolvency laws that are applied respectively in Hong Kong and China, the combined factors of diversity (the advantage) and uncertainty (the disadvantage) can result in creating an incentive for opportunistic behaviour such as forum shopping. Given the purpose of shopping for court forums is to obtain a more favourable judgment from a court more friendly to them, this makes the concept of insolvency claims more vicarious, akin to a lottery game. Conversely, a formal judicial recognition mechanism can help achieve a result that a clearly stated insolvency procedure should bring forth as a matter of course and with legal certainty for all concerned parties. Elaborating further in the next section, the author will first discuss the alternatives available for providing solutions to the regional conflict of laws issue linked with HK-China CBI matters and then explain why a special arrangement, which is likely to be modelled after the 2006 Arrangement, will provide a better solution than other alternatives.

28 Tamanaha (n 25 above), p 375. 
3. Alternatives: Why is a Special Arrangement Better?

Of the three viable alternatives for attaining judicial recognition, namely: (1) a special arrangement focused on HK-China CBI matters; (2) a MoU between Hong Kong and Chinese courts; and (3) a private parties' Choice of Court Agreement; the first two alternatives can each develop into a formal mechanism with long-term mutual judicial recognition application for $\mathrm{HK}-\mathrm{China} \mathrm{CBI}$ cases. A special arrangement may be preferable to a MoU for its wider application and, consequently, far-reaching effect in terms of the courts in which it applies and the categories of judicial decisions for which it applies. The 2006 Arrangement, which is a type of special arrangement, attests to this point; the Chinese courts whose judgments will benefit (ie, the Hong Kong courts will recognise them) from the 2006 Arrangement include the Supreme People's Court, 47 Basic People's Courts in 12 provinces (ie, Guangdong, Shandong, Hebei, Hubei, Liaoning, Jiangsu, Jilin, Zhejiang, Henan, Sichuan, Hainan and Anhui), two municipalities (ie, Shanghai and Tianjin) and one autonomous region (ie, Inner Mongolia). ${ }^{29}$ Also, it is worthwhile to note that the 2006 Arrangement restricts its application to "an enforceable final judgment", which is any judgment made by the Supreme People's Court and any judgment of the first instance made by a Higher or Intermediate People's Court or a Basic People's Court that has been authorised to hear cases concerning parties of foreign countries, Hong Kong, Macao and Taiwan as from 31 May 2006. ${ }^{30}$ Conversely, on the Hong Kong side, any "legally effective judgments" made by "the Court of Final Appeal, the Court of Appeal, and the Court of First Instance of the High Court and the District Court" ${ }^{\prime 31}$ are subject to the 2006 Arrangement's application. Presumably, the 2006

\footnotetext{
${ }^{29}$ Annex to the 2006 Agreement is titled "List of Basic People's Courts of the Mainland Authorised to Exercise Jurisdiction of the First Instance in Civil and Commercial Cases Involving Foreign, Hong Kong, Macao and Taiwan Parties as at 31 May 2006".

${ }^{30}$ Supreme People's Court, "Interpretation by the Supreme People's Court on the Arrangement on Reciprocal Recognition and Enforcement of Judgments in Civil and Commercial Matters by the Courts of the Mainland and of the Hong Kong Special Administrative Region Pursuant to Choice of Court Arrangements between Parties Concerned", Art 2, para (1).

${ }^{31}$ Ibid., Art 2, para (2).
} 
Arrangement was designed to have far-reaching effect as it compels a long list of courts to apply it, as noted above. In terms of categories of judicial decisions, the 2006 Arrangement has wide coverage which includes "judgments, rulings, conciliation statements, orders of payment of the People's Courts in the Mainland and judgments, orders and allocaturs in the Hong Kong SAR" ${ }^{32}$ It can be envisaged that the special arrangement is likely to be modelled after the 2006 Arrangement since the latter has set out the basic framework for judicial recognition of Hong Kong-China commercial cases (but not for insolvency cases). If and when the special arrangement becomes a formal mechanism for mutual judicial recognition of HK-China CBI judgments and orders, it will create a profound legal effect fitting to legal pluralism.

Given that the HKSAR is treated as a foreign jurisdiction by China even after Hong Kong's reversion of sovereignty to China over 17 years ago, judicial recognition requires putting in place either several MoUs or other arrangements. A formal judicial recognition mechanism similar to the 2006 Arrangement apparently has a wider application than several MoUs. A MoU is usually signed between two administrative organs such as in "Notice of the State Administration of Taxation on Issuing the Protocol and the Memorandum of Understanding to the 'Arrangement between the Mainland of China and the Macao Special Administrative Region for the Avoidance of Double Taxation and the Prevention of Fiscal Evasion with Respect to Taxes on Income"'. ${ }^{33}$ Unfortunately no MoU has been signed by Hong Kong and Chinese courts that focuses on judicial recognition, which can be attested by Professors Xianchu Zhang and Philip Smart who opined that "[l]ack of any bilateral agreement in this regard has seen in recent years quite a few cases of controversial interpretations of parties' jurisdictional agreement, parallel proceedings resulting in

\footnotetext{
${ }^{32}$ Zhang and Smart (n 10 above), p 564.

${ }^{33}$ State Administration of Taxation, Guo Shui Han [2009] No 396, 24 July 2009.
} 
conflicting judgments, purposeful selection of forum..." (emphasis added). ${ }^{34}$ On the other hand, during the negotiations over the 2006 Arrangement, there were proposals put forward suggesting the creation of "individual agreements between the concerned SAR and the province or municipality directly under the Central Government in the Mainland" (emphasis added). ${ }^{35}$ Such individual agreements will be akin to a conventional MoU, in both form and substance. The success of individual agreements will likely be determined by the level of engagement and cooperation committed by counterparty courts who had previously agreed to provide judicial assistance and recognition on mutual consensus. It can be envisaged that numerous bilateral agreements between various levels of courts in Hong Kong and China will have to be signed individually to guarantee a reliable result, thus creating unnecessary administrative burdens and costs. A series of MoUs, in much the same vein as individual agreements, can possibly qualify as a formal judicial recognition mechanism, although with less far-reaching effect compared with the signing of a special arrangement since such agreements are most likely to be signed on an individual basis.

The technical difficulty - in appraising which legal alternative is most suitable for adoption as a formal judicial recognition mechanism - cannot be tempered without reference to the Basic Law, the de facto constitution of the HKSAR. However, the complexity of bilateral/mutual judicial recognition issues is further compounded with the vagueness of the Basic Law. Article 95 of the Basic Law merely states that "[t]he Hong Kong SAR may, through consultations and in accordance with law, maintain judicial relations with the judicial organs of other parts of the country, and they may render assistance to each other". ${ }^{36}$ As

\footnotetext{
${ }^{34}$ Zhang and Smart (n 10 above), p 561.

${ }^{35}$ Ibid., p 560.

36 The Basic Law of Hong Kong, Art 95.
} 
Professors Xianchu Zhang and Philip Smart pointed out, "[a]lthough the article provides the legal basis for cross-border judicial cooperation, it fails to specify any detail". ${ }^{37}$

\section{Institutions Interplay with the Operation of Insolvency Laws in Hong Kong and China}

China's accession to the World Trade Organisation on 11 December 2001 invoked institutional changes which are marked by continuous reforms having been carried out in China for improving governance at various socioeconomic levels. Reforms (legal, social or economic) are usually evolutionary rather than revolutionary in order to fit in China's "orderly and gradual" transition to a "socialist market economy", an idiosyncratic socioeconomic context which was introduced by Deng Xiaoping (a former Chinese political leader from 1978 to 1992). The "socialist market economy" system is signified by the power of the state melded with the power of capitalism; this practically means that "state-owned and state-controlled enterprises continue to control the commanding heights of the Chinese economy even though market-oriented reforms have led to a rapid expansion of the private sector in China". ${ }^{38}$ As China continues to reform and develop a rather complex socioeconomic infrastructure, the implications are twofold. First, institutional changes were conducive to legal and economic developments in China over the past three decades as the central government made the country into a magnet for foreign investors who saw China as an emerging market economy with immense business opportunities. In 2010, China surpassed Japan as the world's second-largest economy, ${ }^{39}$ a gain from "adaptive efficiency" which, as suggested by Nobel Prize laureate Douglass C North, "is concerned with the kinds of rules that shape the way an economy evolves through time". ${ }^{40}$ In other words, institutional rules evolve along with the way in which an economy evolves; institutional rules and norms are

\footnotetext{
${ }^{37}$ Zhang and Smart (n 10 above), p 560.

${ }^{38}$ Ming Du, "China's State Capitalism and World Trade Law" (2014) 63(2) International and Comparative Law Quarterly 409, 409.

${ }^{39}$ Kevin Hamlin, "China Overtakes Japan as World's Second-Largest Economy" Bloomberg News (16 August 2010), 1-5.

${ }^{40}$ North (n 3 above), p 80.
} 
formed in order to sustain and guarantee economic growth. To prevent the economy from suffering the effects of failed business enterprises, an insolvency regime should aim to provide a fair solution for the debtor company, its creditors and other stakeholders such as employees, shareholders, suppliers and even the investing public (if the debtor company is a listed public company). Second, market reform in China has led to a rapid expansion of the private sector - if the private enterprise's business went well, investors could profit from successful business investments; but if the business failed, one often finds that the insolvency of private enterprises in China is not a private matter at all. Once an insolvency petition is lodged with the Chinese court by either the debtor company or its creditor(s), the insolvency procedure will involve a team of officials and governmental departments which will take the helm of relevant insolvency proceedings. ${ }^{41}$

Since private parties cannot contract out insolvency law, a private party agreement on choice of jurisdiction cannot apply in HK-China CBI cases unless it is compatible with the operation of insolvency laws in both Hong Kong and China. This exposes the limit in relying on a private party agreement to enforce a favourable judgment, whereas formal judicial recognition affords a more radical resolution. Therefore, one of the main reasons for supporting pluralistic alternatives should be the ease with which judicial recognition or assistance can be obtained from the court that has the jurisdiction and authority to grant it. Pluralistic alternatives often interact and intertwine with the institutions' functionalism. That is because institutions provide a legal or contractual structure for law enforcement purposes. Institutions can be formal and informal ${ }^{42}$ - examples of the former are treaty, law and rules and examples of the latter are customs, traditions and any informal constraints "which are extensions, elaborations and qualifications of rules and have tenacious survival ability

\footnotetext{
${ }^{41}$ Emily Lee and Karen Ho, "China's New Enterprise Bankruptcy Law—A Great Leap Forward, but Just How Far" (2010) 19 International Insolvency Review 145, 156.

${ }^{42}$ Luis Diego Canseco and Enrique Pasquel, "State Decisis, Commercial Exchanges and Predictability: A Proposal to Confront the Reform of the Judicial Branch" (2008) 20 Florida Journal of International Law 31.
} 
because they have become part of habitual behaviour". ${ }^{43}$ On the other hand, contractual agreements are more easily acceptable for contracting parties as they give bargaining strength to the parties and set out the contractual terms and conditions that formed the economic exchange. In the context of HK-China CBI matters, informal institution refers to a private party contract or agreement that shall presumably include the judicial recognition clause through which contracting parties agree to have a specified court as the sole jurisdiction to adjudicate on CBI matters. Since the contracting parties' choice of jurisdiction is not always honoured if and when it goes against the operation of insolvency law, institutions will complement the rational choice theory because they include any form of constraint that helps shape the behaviour of the party acting within the parameters of a regulatory, social or cultural framework. ${ }^{44}$

\section{Institutionalism and Legal Pluralism}

Institutionalism crosses over with legal pluralism in circumstances where formal or informal institutions provide a legal framework for testing the institutional value of legal pluralist alternatives whose sustainability can only be proved if accompanied by functional practicality. It is safe to say legal pluralistic alternatives must play out within institutional constraints. While legal pluralism is central to the fundamental jurisprudential quest for answers to what constitutes as law and what the law requires, the law must operate alongside the political system. Under the Chinese politico-legal system, the signing of a MoU or a special arrangement can provide certainty that helps reduce transaction costs associated with commercial activities. Since formal institutions such as a MoU or a special arrangement would in all likelihood be optimised by state departments that subscribed to them, these institutional arrangements facilitate and solidify commercial engagements in HK-China

\footnotetext{
${ }^{43}$ North (n 3 above), p 83.

${ }^{44}$ Ibid., p 4.
} 
cross-border trade because without these arrangements, transaction costs (including those required for enforcing $\mathrm{HK}-\mathrm{China} \mathrm{CBI}$ claims) would increase exponentially when parties are forced to undergo duplicative insolvency proceedings in both Hong Kong and China. Once a formal mechanism such as a MoU or a special arrangement is put in place, it will be less likely subject to the political goodwill of concerned state departments in cementing the cooperation among them who had allowed themselves to be bound by a MoU or a special arrangement.

Legal pluralism provides a good way to evaluate normatively the interpretive choices of interested parties who may be entitled to rely on either one of the institutional alternatives: a MoU or a special arrangement for $\mathrm{HK}-\mathrm{China} \mathrm{CBI}$ judicial recognition. The coexistence and competition between these two institutional alternatives suggest that legal pluralism can evolve from theories of political ordering. The political will required by the Supreme People's Court, Chinese central government and HKSAR regional government to avail the signing of a MoU or a special arrangement is precursory to the adoption of any formal mechanism for judicial recognition that focuses on $\mathrm{HK}-\mathrm{China} \mathrm{CBI}$ cases. In this regard, legal pluralism can be examined from a methodological angle in the context of adaptive efficient alternatives that constitute as institutional norms.

All institutions are invariably accompanied by transaction costs and therefore can be replaced by alternatives ${ }^{45}$ therefore the success of either a MoU or a special arrangement will depend on participation by its members (eg, the Supreme People's Court, designated Chinese Courts to adjudicate on HK-China CBI cases, Hong Kong courts, etc.). Notwithstanding that, once a MoU or a special arrangement is harnessed with the status of a formal judicial recognition mechanism for $\mathrm{HK}-$ China $\mathrm{CBI}$ cases, the implementation will no longer be at the

\footnotetext{
${ }^{45}$ Sungjoon Cho, "Beyond Rationality: A Sociological Construction of the World Trade Organisation" (2012) 52(2) Virginia Journal of International Law 321.
} 
whim of the Supreme People's Court, designated Chinese courts or Hong Kong courts. However, in comparison to a formal mechanism such as a MoU or a special arrangement, a private parties' Choice of Court Agreement has a built-in disadvantage: it is not as effective as that of a MoU or a special arrangement, which has the inherent purpose of enabling or granting judicial recognition. For ease of understanding, let us assume there is a Joint Venture (JV) registered in the BVI and whose centre of main business is in Shenzhen, China. The JV agreement between Party A (the investing company in Hong Kong which contributed to the JV with operational capital) and Party B (a local party in China which provided the JV with the land on which the JV is premised) contains a contractual clause specifying that, in the event the JV becomes insolvent, the insolvency procedure should take place in either the Chinese or Hong Kong courts. Let us further assume that Party A failed to comply with the contractual clause by filing an insolvency procedure against the JV in the BVI because its management personnel consider that BVI law is preferable to them. These examples demonstrate that parties are inclined to interpret unilaterally a contractual position in order to minimise the costs for resolving insolvency cases. This unruly pattern of party behaviour reaffirms Douglass C North's theory that a major role of informal constraint (such as that in a contract) is to "modify, supplement, or extend formal rules". ${ }^{46}$ It is on this basis that the author proposes for the signing of a special arrangement that focuses on $\mathrm{HK}-\mathrm{China} \mathrm{CBI}$ matters by the Supreme People's Court in China and the HKSAR government; once established, it would minimise the risks associated with unruly party behaviour that is acted out in the name of party autonomy.

\section{Conclusion}

The problems of HK-China CBI issues have direct impact on the HKSAR's desire and ability in maintaining its reputation as a key international financial centre in the world while

${ }^{46}$ North (n 3 above), p 87. 
maintaining strong economic ties with China. The $\mathrm{HK}-\mathrm{China} \mathrm{CBI}$ judicial recognition mechanism should be made available for companies and insolvency practitioners in the HKSAR and China so as to simplify as well as unify the insolvency procedures in both jurisdictions. Judicial recognition lies at the heart of CBI disputes because they concern failing or failed debtor companies whose creditors, assets and/or place of incorporation are located in different jurisdictions. Without judicial recognition, a party seeking to enforce a CBI judgment made by a Hong Kong court against a counterparty in China must initiate separate insolvency proceedings in China. The dangers of duplicated law suits are not merely wasted judicial resources, time and costs; without judicial recognition, similarly situated creditors may be awarded different judgments by different courts, creating an incentive for forum shopping by creditors.

If a formal mechanism can be established for mutual recognition and enforcement of judgments or orders made by either the Hong Kong or Chinese courts on HK-China CBI matters, not only will the courts and insolvency practitioners in Hong Kong and China benefit, but the international scholar community and government policy makers will also benefit from the dissemination of insights and experiences gained from the study and practice of law in this specialised area. HK-China CBI matters have strong economic implication for both Hong Kong and China and, as such, the issue warrants a close study of all legal options that will help cement the commercial engagements between Hong Kong and China. 